\title{
Reduced infiltration of T-regulatory cells in tumours from mice fed daily with gamma-tocotrienol supplementation
}

\author{
Shonia Subramaniam ${ }^{1}$, Jeya Seela Anandha Rao ${ }^{1}$, Premdass Ramdas ${ }^{1}$, Mei Han $\mathrm{Ng}^{2}$, \\ Methil Kannan Kutty ${ }^{3}$, Kanga Rani Selvaduray ${ }^{2}$, and Ammu Kutty Radhakrishnan ${ }^{4}$ \\ ${ }^{1}$ International Medical University \\ ${ }^{2}$ Malaysian Palm Oil Board \\ ${ }^{3}$ Lincoln University College \\ ${ }^{4}$ Monash University Malaysia
}

May 24, 2021

\begin{abstract}
Gamma-tocotrienol $(\gamma \mathrm{T} 3)$ is an analogue of vitamin E with beneficial effects on the immune system, including immunemodulatory properties. This study reports the immune-modulatory effects of daily supplementation of $\gamma \mathrm{T} 3$ on host T-helper (Th) and T-regulatory (Treg) populations in a syngeneic mouse model of breast cancer. Female BALB/c mice were fed with either $\gamma \mathrm{T} 3$ or vehicle (soy oil) for 2-weeks via oral gavage before they were inoculated with syngeneic 4T1 mouse mammary cancer cells $(4 \mathrm{~T} 1$ cells). Supplementation continued until the mice were sacrificed. Mice $(\mathrm{n}=6)$ were sacrificed at specified time-points for various analysis (blood leucocyte, cytokine production, and immunohistochemistry). Tumour volume was measured once every seven days. Gene expression studies were carried out on tumour-specific T-lymphocytes isolated from splenic cultures. Supplementation with $\gamma \mathrm{T} 3$ increased CD4+ $(\mathrm{p}<0.05)$, CD8+ $(\mathrm{p}<0.05)$ T-cells and natural killer cells $(\mathrm{p}<0.05)$ but suppressed Treg cells $(\mathrm{p}<0.05)$ in peripheral blood when compared to animals fed with the vehicle. Higher interferon-gamma (IFN?) and lower transforming growth factor-beta (TGF-?) levels were noted in the ?T3 fed mice. Immunohistochemistry findings revealed higher infiltration of CD4+ cells, increased expression of interleukin-12 receptor-beta-2 (IL-12?2R), interleukin-24 (IL-24) and reduced expression of cells that express the forkhead box P3 (FoxP3) in tumours from the ?T3 fed animals. Gene expression studies showed the downregulation of seven prominent genes in splenic CD4+ T-cells isolated from $\gamma$ T3-fed mice. Supplementation with $\gamma \mathrm{T} 3$ from palm oil-induced T-cell dependent cell-mediated immune responses and suppressed Treg cells in the tumour microenvironment in a syngeneic mouse model of $\mathrm{BC}$.
\end{abstract}

\section{Hosted file}

Manuscript.docx available at https://authorea.com/users/415476/articles/523359-reducedinfiltration-of-t-regulatory-cells-in-tumours-from-mice-fed-daily-with-gammatocotrienol-supplementation 